\title{
article
}

\section{From psycho-politics to mad studies: learning from the legacy of Peter Sedgwick}

\author{
Peter Beresford, peter.beresford@brunel.ac.uk \\ Brunel University London, UK
}

\begin{abstract}
We now have a new kind of psycho-politics; a brutal and destructive alliance between neoliberalism and an expanding psychiatric empire. This article will explore how mental health service users/ survivors and other mental health campaigners can connect with the critical analysis and action embodied in the work and values of Peter Sedgwick at a time of crisis and reaction. They have seen ideas like 'user involvement' and 'recovery' co-opted and undermined, and both their experiences and aspirations individualised and devalued. Emerging interest in mad studies, it is suggested, offers a way forward that challenges both the marketisation and medicalisation of people's distress. This discussion will explore the continuities and discontinuities with Peter Sedgwick's pioneering work and highlight, as he did, the importance of making explicit the political and ideological relations of survivors' struggles within and against the psychiatric system.
\end{abstract}

key words Sedgwick • mad studies • psychiatry • user movements

\section{The relevance of Sedgwick}

The republication of Peter Sedgwick's Psycho politics in 2015, after a gap of more than 30 years, suggests that it may have a new relevance (Sedgwick, 1982, 2015). A point of this article is that it does have. What is unlikely, though, is that we will be reading it simply in its own right. Instead, it is more likely to attract the attention of mental health service users/survivors and allies primarily committed to analysing and transforming the existing psychiatric system (Cresswell and Spandler, 2009). We can expect the search to be for insights that may be helpful in that task, rather than to rediscover or make better sense of Sedgwick and his ideas, both political and psychological. To be truthful, that is also the main interest of this author. This orientation may not do the fullest justice to the contribution Sedgwick may have made. However, I would argue that it is understandable given the catastrophic state of policy, services, thinking and support for people experiencing distress, and also the uncertain position of survivors' self-organisation in the face of this. These are all issues that concerned Sedgwick himself.

Such a specific pressure for re-examining Sedgwick and his work may limit the gains to be got from it. However, equally, there are likely to be other obstacles in the way of reassessing his work adequately. The past is certainly a different country and it seems particularly important that we are coming at Sedgwick from a very different age. He remains unusual among commentators on distress, psychiatry and 
contemporary thought in that he came at them from a strong political position. We have grown used to commentators more influenced by and concerned with professional, policy, personal, academic, research and emancipatory perspectives and agendas. Sedgwick could identify as a service user, academic and as a professional (educational psychologist), but he also occupied communist and socialist ideological positions and all his writings were closely connected with these, and his written work was far from being confined to the subjects of 'social policy' and 'mental health'. This makes him very unusual among commentators either of his time or since, who have primarily come from within the ranks of the psychiatric system, whether as providers, recipients or analysts and researchers.

Thus, Sedgwick's style and approach is more like that of political writings of the time than of social policy ones. Also, it is not just that they reflect a different age and different preoccupations. It is also difficult to know whether he could have imagined that Thatcherism or, as we have come to call it, neoliberalism could have lasted as long as it has. Instead of it being a blip in UK and international political and ideological history, it has made major developments like the UK welfare state and the post-Second World War social-democratic settlement look more like timelimited blips themselves.

\section{Welfare state failure on mental health policy}

We need to remind ourselves that Psycho politics was first published in 1982, a year after the Falklands War, and written when Mrs Thatcher's popularity was at a very low ebb. Her popularity boomed as a result of the war and she won the general election in June 1983 with the most decisive election victory since that of Labour in 1945 (Butler and Kavanagh, 1984). Whatever the reasons for this - the Social Democratic Party's splitting of the opposition vote, the anomalies of the electoral system or the increasing dominance of right-wing media - it signalled a shift to the political Right that we are still living with. A few months after Thatcher's victory, Sedgwick was dead.

What some saw as liberatory developments, for example, the critiques of Foucault, Szasz, Laing and Goffman, he saw as potentially conservative ones. That is not to say, however, that he equated this with a much longer-term, deeply engrained shift to the political Right; rather, that he saw these as misguided efforts to advance mental health policy, practice and theory among leftists and under traditional left-of-centre politics (Mason, 1983). He was concerned that anti-psychiatry attitudes would play into the hands of Thatcherites committed to cutting public services and state spending. However, at the time, there was uncertainty and disagreement as to whether Mrs Thatcher merely represented more of the same or was a radical departure from what people had been used to (Lee, 1983: 22; Taylor-Gooby, 1985: 71). This is the first key point that we need to grapple with, both in trying to make sense of Sedgwick and in learning from him: the massive degree to which times have changed and with what seems accelerating speed.

When Sedgwick was writing, mental health policy and provision was both going through a process of change and coming under attack as outmoded and inadequate. From the 1960s, the government plan was to cut the number of mental health hospital beds, but this took place slowly, without adequate or appropriate alternatives 
being offered and with appalling conditions being reported by official inquiries and whistle-blowers (Pilgrim and Rogers, 1996; Gostin, 2010).

Such mental health policy needs to be put in the context of the welfare state in which it operated. The welfare state that was created after the Second World War of 1939-45 broke with much that had gone before. It sought to provide: decent council housing for all in need; an income maintenance system that broke with past ideas that it was people's own fault if they did not have a job or could not manage; and a free national health service. Most of all, it was based on an idea of full employment: that there should be jobs available for those who needed them and that they should not be at the mercy of market cycles and the poverty and insecurity that went with them.

With hindsight, we can also clearly see the original welfare state's two great failings: first, that it was essentially paternalistic, seeking to improve conditions for people and do good for them without including or involving them in the process; and, second, that it failed to treat difference with equality, or even adequately to take account of it. So, for women, it was back to the home, back to a subordinate role, and around all the dimensions of equality, race, sexuality, class, culture, belief and disability, the welfare state was a prisoner of its age, although its advocates did much to challenge this in the intervening years (Beresford, 2016). However, there is also one more major failing less often discussed that has affected mental health policy ever since: it laid down a post-war approach that failed to break from the past. It was still based on and reinforced a dominant narrow medical model. It was increasingly over-reliant on drug treatments. It was still based on individualised, pathologising understandings, closely linked with compulsion, stigma, secrecy and abuse, and still too often institutionalising. Physical and mental health were understood and treated in very different ways. While the former came in for radical transformation, the only fundamental change affecting the latter was an increasing and disproportionate reliance on drug 'treatments'.

So, as Sedgwick understood only too well, there was no golden age of mental health policy and practice under the post-war welfare state. The 'radical' developments of which he was critical arguably resulted in little improvement to the overall system. However, where we are now is somewhere very different and essentially unfamiliar to Sedgwick.

\section{A new politics and changed mental health policy}

More than 30 years of neoliberal politics, underpinned by a notion of human nature as selfish rather than altruistic, have been linked with an accelerating commitment to the market rather than the state, increasing social inequality and a trend to cuts in public services and spending, especially over the last five years. One consequence of the emergence of neoliberal governments like the present UK one is that they have formed a powerful alliance with traditional, dominant and expanding psychiatry. Mental health services may be under attack but 'psych-thinking' is on the upsurge.

This expansion of psychiatry is reflected in: the massively growing range of psychiatric diagnostic categories (APA, 2014); their application to more groups and the routine use of associated psychotropic drugs for a widening range of people, issues and situations, for example, children and young people experiencing difficulties in school and the family; older people in institutional settings and people with learning difficulties identified as having 'challenging behaviour'; as well as increasing interest in 
organic, genetic and bioethical approaches to madness and distress (Johnstone, 2014). Both neoliberalism and mainstream psychiatry individualise responsibility and frame understanding in terms of individual rather than social causes and analysis. In the UK, mental health policy and services have been chronically underfunded, community and support services have suffered increasing cuts, and there has been a shift to more control and forensic services and away from support services.

However, policy responses to madness and distress in the UK have to be considered more broadly than just in relation to dedicated mental health provision. So-called welfare reform - initiated by New Labour governments and drastically extended by the subsequent Coalition and then Conservative governments - has taken reactionary policy against mental health service users to new levels. Combined right-wing media and political campaigns have been associated with rising levels of stigma, hate crime, anxiety, distress, suicidal thoughts and actual suicide among mental health service users (Ryan, 2015). Cuts in other key public services, like housing, training and recreation, and the whittling away of social work, social care and childcare, have also had massively damaging effects on many service users.

Thus, present UK policy in relation to mental health is significantly different to both of those with which Sedgwick was familiar: the failed one of the post-war welfare state settlement and the efforts to deinstitutionalise under neoliberalism/Thatcherism. Instead, we have policy and provision rooted in a model of 'recovery' ideologically led by a commitment to get service users off benefits and into employment, a notion of service throughput rather than long-term support, and an increasing expectation of increased reliance on family support and marginalised 'peer support' workers (Beresford et al, 2016).

The broader direction of travel of neoliberal governments has further implications for madness and distress. In the UK, under the rationale of austerity, this has been associated with reducing the role of the state as a provider of support, while nonetheless seeming to reinforce its role in control. There is a constant divisive rhetoric, setting up divisions between people as 'strivers' and 'skivers', citizens and immigrants, wealth-creating and consuming, and dependent and independent. The watchword is competition rather than collaboration, with individuals, communities and interest groups having to fight each other for ever-diminishing pots of public money, while large corporations and the super-rich pay proportionately less tax. It has become an age of uncertainty, fear and anxiety, with key aspects of people's lives like employment, housing, retirement and social care increasingly insecure and uncertain. Heightened threats to national security are identified, from different generations - the young versus the baby boomers - and from different faiths and cultures. As material conditions for the majority either deteriorate or stagnate, we are encouraged to be 'aspirational', denying who we actually are and creating alternative fantasies, as well as to distance ourselves from our peers as 'other'.

\section{A maddening politics}

Such policies seem committed to the generation of mental ill health and distress, rather than to reducing it. There is now strong evidence that the increasing inequality associated with such neoliberal politics and ideology has damaging effects on the physical and mental health of most, if not all, of us (Wilkinson and Pickett, 2009). While the consequences of such inequality are widely felt across social groups, 
it is particularly damaging to those on lower incomes and included in the lower socio-economic groups, being associated with higher morbidity and mortality rates (Dorling, 2013).

So, we can hardly look to this as a politics that is likely to take seriously mental health policy and practice when it is one that is essentially distressing and maddening. It is a politics that seeks to make you deny who you are and hate everyone else by othering them. In my view, this makes it a politics of madness. Its appalling record on and dismantling of mental health policy is, of course, just a part of this bigger denial and approach.

Such government policy is irrational and maddening because it rejects evidence; it ignores the experience of service users. Service users like me have long highlighted the importance of policy and practice giving equal value to experiential knowledge, the knowledge that comes from lived experience and service users' realities, as well as traditional expert knowledge generated by research and professionals (Beresford, 2003). Governments like the present UK government, however, have made clear that they devalue and ignore both expert and experiential knowledge. Thus, we have a new politics and heavily politicised social policy that, if anything, makes politically based critiques like Sedgwick's more relevant, even if the terms of reference and specific issues may have changed.

We need an ideologically informed response and critique to deal with this. Sedgwick offered a powerful warning of the importance of this. As he rightly said, turning to a libertarian right-wing thinker like Thomas Szasz for understanding and reform is unlikely to be a good idea for those of us committed to collectivist responses to social and personal problems. Yet, there seems to have been little acknowledgement of the extremism of recent government policy relating to mental health and the sharply worsening situation of many mental health service users in much of the mainstream response to it. While welfare reform, for example, has been particularly damaging and destabilising for mental health service users, this is not reflected in high-level discussion. Instead, we have had high-profile begging letters from celebrities and politicians asking for parity between physical and mental health services. National MIND criticises councils for not spending 1\% of their budgets on mental (ill) health prevention - all this at a time of unprecedented cuts in public services and provision (Meickle, 2015; Morris, 2015).

Perhaps the first lesson to learn from Sedgwick is the importance of having a political understanding and to address ideology if a helpful and successful challenge is to be made to the dominant reactionary model of psychiatry now operating within neoliberal politics. Even if times have changed, the present heavily politicised context of mental health issues gives added relevance to Sedgwick's approach and understanding.

Perhaps the second lesson that Sedgwick offers comes from the fact that he was as critical of many of the opponents of conventional mental health policy and thinking as he was of those then prevailing. He did not make the easy assumption that the enemies of poor policy were necessarily the friends of mental health service users/survivors. Psycho politics is largely made up of an analysis of what he saw as the shortcomings of contemporary radicals and associated interpretations of madness and distress. $\mathrm{He}$ is largely dismissive in his evaluation of Erving Goffman, R.D. Laing, Michel Foucault and Thomas Szasz. There are significant differences between these commentators, but what they have in common is that their primary relationship with madness and 
distress was professional rather than personal. Goffman was a sociologist and writer; Laing was a psychiatrist and writer; Foucault was a French philosopher, critic and social theorist; and Szasz was a psychiatrist and academic. They were all engaged with the subject as professional experts, rather than being involved or caught up in it on the receiving end. What distinguishes the survivor movement that emerged in the 1980s and 1990s is that it was based precisely on this shared characteristic - of experiential knowledge. While the important role of supportive allies was quickly recognised, a defining characteristic of independent survivor organisations rapidly became that they were run by people with lived experience of madness, distress and the psychiatric system. ${ }^{1}$ Looking back from our present vantage point, Sedgwick's suspiciousness of professional critiques seems both significant and prescient. Since that time, a strong case can be made that the most influential and radical analyses of mental health (and, indeed, of disability and health and welfare policies more generally) have come not from professional commentators and radicals, but from service users themselves. Thus, the social model of disability, the philosophy of independent living and ideas of self-advocacy have all come from people with lived experience on the receiving end of professional practice and thinking (Oliver and Barnes, 1998, 2012). The survivor movement in the UK has not developed a corresponding social model of madness and distress - indeed, there is some suspicion of such an approach - but it has undoubtedly been generally committed to a more social approach to 'mental health' (Beresford et al, 2016). This corresponds with Sedgwick's position. He did not counterpose the medical and social models, but, as we shall see, he was familiar with a less medicalised psychiatry than we are today.

While some mental health service user/survivor activists value pioneers dismissed by Sedgwick, like Szasz and Laing, and see them as part of their own development, one of the defining characteristics of the survivor movement internationally has been the desire to speak and act for yourself. There has been a determination, especially on the part of more radical organisations like Survivors Speak Out, for self-empowerment and self-organisation. At its heart, this suggests the same suspiciousness and distrust of professionals and reliance on professional leaders reflected in Psycho politics. Survivors and their organisations have been innovative and pioneering.

Sedgwick was clearly in tune with this desire on the part of such movements to develop their own voices and take charge themselves, although he was not directly linked to such organisations; instead, as we have seen, what affiliations he had were mainly with left-wing political organisations. Already writing in the early 1980s, he talks in Psycho politics of 'the active consumer groups which have sprung up', seeing them as 'wiser than those theorists' of whom he was critical (Sedgwick, 1982: 197).

Sedgwick sought to highlight what he saw as conservative, simplistic and unhelpful undercurrents in the professional psychiatric radicalism of his time. He challenged individualistic understandings, interpretations and solutions. Survivors were generally not in equal relationship with those self-appointed radicals. The latter could offer hope in times when hope was often in short supply, but generally this was not an equal alliance. Their radicalism could also sometimes be read as a more intra- and inter-professional struggle than a liberatory one. 


\section{The paradox of the survivor movement}

At the same time, it is important to remember his essential pessimism about the possibilities of mental health service user movements. He recognised the opportunities offered by broader political and cultural radicalisation in the late 1960s and 1970s (Sedgwick, 1982: 211). However, he saw such chances as restricted in the psychiatric context because 'mental patients are among the most private of citizens', which he saw as limiting their capacity for 'common association and organisation'. He highlighted the stigma associated with them as 'preventing them asserting a group identity in public' (Sedgwick, 1982: 222). He believed that where such initiatives did develop, mental patients restricted themselves to a 'defensive role within the framework of the institution ... limiting themselves to demanding control over existing forms of care' rather than working for alternatives outside it (Sedgwick, 1982: 229). He also felt that the potential of self-organisation was restricted because:

consumers in the psychiatric arena (as on other fronts of welfare politics) will find themselves juxtaposed awkwardly between the paternalistic, parsimonious inheritance of socially funded institutions bequeathed from the Keynesian era of the second world war (and its sequels in the different national post-war settlements) and the advancing counter-revolution of welfare cutbacks and other dilapidations decreed by right-moving governments in the present period of recession and militarism. (Sedgwick, 1982: 245)

There may be some truth in all of Sedgwick's points, but we have nonetheless seen user movements among both mental health service users and beyond develop and grow enormously since the 1980s. His poor opinion of the prospects of the user movement and its organisations is interesting. However, it is important to remember how much they have achieved. They have developed both ideas and practice in relation to user-led, non-medicalised services like crisis houses, telephone helplines, direct payment schemes and personal support schemes, housing and employment support, advice and advocacy schemes, and specific support for black and minority ethnic service users (Chamberlin, 1988; O’Hagan, 1993; Barnes and Mercer, 2006). They have developed groundbreaking ideas like 'recovery' and 'peer support', even though these have been subverted by policymakers and the service system.

However, there is not necessarily a contradiction between Sedgwick's low expectations - although some of them have been proved wrong - and the actual collective achievements of survivors since. While they have had visionary, groundbreaking ideas and an increasing impact, the movement has long been insecure and poorly resourced, and its ideas have been frequently undermined by policymakers and the service system (Wallcraft et al, 2003; Campbell, 2005, 2009). As the UK experience has highlighted, there are continuing fundamental problems restricting the scale, inclusivity and capacity of the survivor movement. Some have even questioned whether it exists as an independent entity. Many of Sedgwick's concerns have been justified.

Historically, the survivor movement has not had its own distinct philosophy or theoretical underpinning, like the disabled people's movement has with the social model of disability (Barnes and Shardlow, 1996; Barnes et al, 1999; Beresford et al, 2009). Due to service users' fears for their peers in the psychiatric system, it has 
always been more focused on reforming it from within, a task that psychiatry has seemed remarkably capable of resisting, with the latter's scope and strength actually increasing over the last 30 years rather than diminishing.

As Sedgwick's criticism of anti-psychiatry might suggest, his own position was not simply one opposed to psychiatry. He made it clear that he saw it as part of the 'socialised medicine' that he advocated and supported. However, the psychiatry that he espoused was the social psychiatry that was on the ascendant after the Second World War, which drew upon and valued disciplines and fields like sociology, social anthropology, cultural psychiatry and social psychology. This was the psychiatry that explored and highlighted the effects of socio-economic factors in distress and pioneered new relationships between services, service workers and service users and communities, embodied in innovations like therapeutic communities. However, such social psychiatry has more recently been in retreat, with bio-psychiatry increasingly dominant (Bentall, 2016).

The strength of the survivor movement has tended to be at the local level; traditional charities still have a much stronger voice at the national and international levels (Beresford, 2010). To sum up, as survivors, it has been difficult for us to be either autonomous or separatist. This has often left us vulnerable, and open to manipulation, subversion and tokenism. These are constant themes in relation to user involvement and the psychiatric system. The latter seems to have an infinite capacity to marginalise survivors' influence, and to extend its power. Not least, it is greatly skilled at turning our own ideas against us and co-opting what could be liberatory possibilities into at best meaningless and at worst damaging developments. We have seen this, as has already been noted, with key ideas and policies of recovery, peer support, personalisation, self-management and rights - where service users' demand for the right to paid work, for example, has been reduced to the obligation of getting off benefits, however damaging to us, and getting a job, any job, however damaging and distressing.

I believe that as survivors seeking to build and safeguard our movement and selforganisation, we have had to learn a fundamental lesson - and it is one that Sedgwick also teaches us. We need to have confidence in our own ideas as our starting point, our own discussions, experiences and knowledges in all their diversity. So, crucially, what I have gained from Peter Sedgwick - reinforcing my own experience - is to be cautious about ideas and approaches that have not involved survivors on equal terms and that are not based primarily on the lived experience and resulting experiential knowledge of service users.

\section{The emergence of mad studies}

Significantly, this is one of the core principles underpinning what can be seen as the latest international development in the field of madness and distress: mad studies. Mad studies, a pioneering new development emerging in the 21st century, can be seen to be directly linked to principles first emphasised by Sedgwick. This is not to say that there are not tensions between Sedgwick and mad studies, that we can know what Sedgwick would have thought of mad studies, or that this author's reading of Sedgwick is the only one to be had. However, these core principles are of central importance and they certainly seem to be shared by Sedgwick and mad studies as currently delineated. It should be said that they have not been embodied in all survivor 
activities, any more than that they were features of anti-psychiatry. However, they are central to mad studies. For this reason, it is important to identify and highlight them.

These are principles of prioritising:

- collectivity;

- being ideologically positioned; and

- building on alliances.

The origins of mad studies are most often traced to work in Canada. International interest in and the visibility of mad studies increased greatly with the publication in 2013 of Mad matters in Canada (Le Francois et al, 2013). While this, the world's first reader in mad studies, made the modest claim of seeking to share and explore ideas and experience from Canada, it has had a watershed effect internationally. Since then, several courses in mad studies have started both in and outside universities in Europe. ${ }^{2}$ In September 2014, there was the first UK mad studies stream at the international disability studies conference at Lancaster University, followed by two more events in $2015,{ }^{3}$ and the establishment of a mad studies networking site ${ }^{4}$ and a Facebook group. ${ }^{5}$

The editors of Mad matters described mad studies as 'a project of inquiry, knowledge production, and political action devoted to the critique and transcendence of psycentred ways of thinking, behaving, relating, and being' (Le Francois et al, 2013: 13). Mad matters has been said to offer 'a critical discussion of mental health and madness in ways that demonstrate the struggles, oppression, resistance, agency and perspectives of Mad people to challenge dominant understandings of "mental illness" (Castrodale, 2015: 3).

Mad matters highlighted ways of melding insight and understanding with making change. Here is the collectivity. Within its pages, we can see 'praxis' and 'conscientisation' as the radical social reformer Paulo Freire understood and argued for them (Freire, 1972). The struggle of mental health service users/survivors against the damaging effects of psychiatry has often seemed a lonely and difficult one. However, this book and related developments are living proof that people with direct experience, supportive professionals, academics, educators and researchers can together take forward mad studies and mad action. Here are the alliances. In the book, no one speaks for others; instead, their own different contributions and understandings from their experience and from working together are offered. Here, we can see the value, the strength and the possibilities of such alliances. The psy-struggle begins to seem much more one that can be won.

Lucy Costa, the Canadian survivor/activist, has offered a helpful definition of mad studies on the mad studies network website. She says that it is:

an area of education, scholarship, and analysis about the experiences, history, culture, political organising, narratives, writings and most importantly, the PEOPLE who identify as: Mad; psychiatric survivors; consumers; service users; mentally ill; patients, neuro-diverse; inmates; disabled - to name a few of the 'identity labels' our community may choose to use.... Mad Studies, right here, right now is breaking new ground. Together, we can cultivate our own theories/models/concepts/principles/hypotheses and values about how we understand ourselves, or our experiences in relationship to mental 
health system(s), research and politics. No one person, or school, or group owns Mad Studies or defines its borders. As explained in the book, Mad Matters, Mad Studies is a, 'project of inquiry, knowledge production and political action'. Presently ... we need more action. (Costa, 2014)

Here, we see mad studies ideologically positioned. Lucy Costa makes clear that she sees mad studies as a cooperative venture, but one led by the experience, ideas and knowledges of 'mad-identified' people. For me, and I hope for many more of us, the power of the new alternative - mad studies - is that it:

- has been grown with survivor involvement;

- $\quad$ is truly international;

- is flourishing and developing;

- $\quad$ is unequivocally non-medical, taking account of the social and the personal and psychological, as well as their relations with each other; and

- makes possible powerful alliances, crucially starting with survivors, survivor knowledges and research.

I have learned to beware of any theory, philosophy, organisation or movement that:

- $\quad$ is not led by service users;

- does not work hard to involve them on equal terms; and

- does not value their experiential knowledge and user-controlled research equally.

So, I believe mad studies is likely to be helpful so long as it:

- $\quad$ is led by us and our experiential knowledge as survivors;

- engages committed allies; and

- $\quad$ is demedicalised and based on a social approach

\section{Sedgwick's prefiguring role}

We need a convincing model to replace the dominant medical model. We know from research with survivors how damaging they feel that the medical model and its drug-dominated corollary is (Beresford et al, 2009). It may not be helpful, but it has been effectively imposed on people socialised to feel inferior and deferential. It has worked; it has seemed to make sense and has carried conviction, and internalising it has often been the only gateway to support and resources.

However, it is wrong for us as survivors to experience personal and social difficulties and then to be written off as abnormal, pathological and deviant. Key battles are now being fought over language and ownership, over knowledge, and over social and collective rather than individual and individualised understandings.

Sedgwick prefigured this, highlighting all these issues in his writings. We owe him a debt and mad studies gives us an unprecedented rallying point for challenging it, not just for us as mental health service users, not just as practitioners, but for everyone, by setting down markers for new understandings compatible with a different, humanistic, holistic, egalitarian and just politics. Sedgwick ended his Psycho politics by referring to 
the centuries-old (collective and socially inspired) therapeutic activity of the Belgian villagers of Geel (Jay, 2014; Dearden, 2015). He wrote:

The work of Geel is indeed the victory of humanity; but not simply via the actions of individual humanitarianism, in the liberal or philanthropic model of welfare. Rather it expresses the practice, voluntarily conceived and materially implemented, of a socialised and organised humanity. The achievement of this kindly and efficacious condition, for all patients and all societies, is the central problem of psychiatric care. It is also the central problem of social liberation. (Sedgwick, 2015: 256, emphasis in original)

Sedgwick's views on Geel might now seem dated or even paternalistic, although his aspirations for it still strike strong chords. We can perhaps see mad studies as both the latest expression of Sedgwick's thinking on this and probably the current development most likely to achieve such hopes - vindicating Sedgwick's pioneering and inspiring work.

\section{Notes}

1. See, for example, http://studymore.org.uk/mpu.htm\#SurvivorsSpeakOut

2. Including: Queen Margaret University, Edinburgh; Northumbria University, NewcastleUpon-Tyne; Mad Studies North East; reading groups in Amsterdam; a seminar series at Humboldt University, Berlin; and more.

3. Mad Studies and Neurodiversity, 17 June 2015, Lancaster University; Making Sense of Mad Studies, 30 September-1 October 2015, Durham University.

4. See: https://madstudies2014.wordpress.com

5. See: https://www.facebook.com/groups/394088527441084/

\section{References}

APA (American Psychiatric Association), 2014, DSM-5 - Diagnostic and statistical manual of mental disorders, Arlington, VA: American Psychiatric Association

Barnes, C, Mercer, G, 2006, Independent futures: Creating user-led disability services in a disabling society, Bristol: The Policy Press in association with the British Association of Social Workers

Barnes, M, Shardlow, P, 1996, Effective consumers and active citizens: strategies for users' influence on service and beyond, Research, Policy and Planning, 14, 1, 3-38

Barnes, M, Harrison, S, Mort, M, Shardlow, P, 1999, Unequal partners: User groups and community care, Bristol: The Policy Press

Bentall, R, 2016, Mental illness is a result of misery yet still we stigmatise it, opinion, The Guardian, 26 February, http://www.theguardian.com/commentisfree/2016/ feb/26/mental-illness-misery-childhood-traumas

Beresford, P, 2003, It's our lives: A short theory of knowledge, distance and experience, London: Citizen Press in association with Shaping Our Lives

Beresford, P, 2010, A straight talking guide to being a mental health service user, Rosson-Wye: PCCS Books

Beresford, P, 2016, All our welfare: Towards participatory social policy, Bristol: The Policy Press

Beresford, P, Nettle, M, Perring, R, 2009, Towards a social model of madness and distress? Exploring what service users say, 22 November, York: Joseph Rowntree Foundation 
Beresford, P, Perring, R, Nettle, M, Wallcraft, J, 2016, From mental illness to a social model of madness and distress, London: Shaping Our Lives and National Survivor User Network

Meickle, J, 2015, Councils Spending Just 1\% of Health Budgets on Mental Health, The Guardian, 9 November, http://www.theguardian.com/society/2015/nov/09/ councils-spending-just-1-of-health-budgets-on-mental-health

Butler, D, Kavanagh, D (eds), 1984, The British general election of 1983, Basingstoke: Macmillan

Campbell, P, 2005, From little acorns: the mental health service users movement, in A Bell and P Lindley (eds) Beyond the water towers: The unfinished revolution in mental health services, 1985-2005, London: Sainsbury Centre for Mental Health

Campbell, P, 2009, The service user/survivor movement, in J Reynolds, R Muston, T Heller, J Leach, M McCormick, J Wallcraft and M Walsh (eds) Mental health still matters, Basingstoke: Palgrave/Macmillan, 46-52

Castrodale, MA, 2015, Book review 'Mad matters: a critical reader in Canadian mad studies', Scandinavian Journal of Disability Research, 17, 3, 284-6

Chamberlin, J, 1988, On our own: Patient controlled alternatives to the mental health system, London: MIND

Costa, L, 2014, Mad Studies - What it is and why you should care, Mad Studies Network, posted October 15, https://madstudies2014.wordpress.com

Cresswell, M, Spandler, H, 2009, Psychopolitics: Peter Sedwick's legacy for mental health movements, Social Theory and Health, 7, 2, 129-47

Dearden, L, 2015, The city where residents have been taking mentally ill people into their homes for hundreds of years, The Independent, 3 October, http://www.independent.co.uk/life-style/health-and-families/health-news/ geel-the-city-where-residents-have-been-taking-mentally-ill-people-into-theirhomes-for-hundreds-of-a6678126.html

Dorling, D, 2013, Unequal health: The scandal of our times, Bristol: Policy Press

Freire, P, 1972, Pegagogy of the oppressed, London: Penguin

Gostin, LO, 2010, From a civil libertarian to a sanitarian: 'a life of learning', Presidential Address for the Faculty Convocation, October, Washington DC, Georgetown University Law Center

Jay, M, 2014, The Geel question: for centuries, a little Belgian town has treated the mentally ill. Why are its medieval methods so successful?, Aeon Essays, 9 January, https://aeon.co/essays/geel-where-the-mentally-ill-are-welcomed-home

Johnstone, L, 2014, A straight-talking introduction to psychiatric diagnosis, Wyastone Leys: PCCS Books

Lee, P, 1983, Welfare state: the second front opens, Marxism Today, May, 22-3

Le Francois, B,A, Menzies, R, Reaume, G, eds, 2013, Mad matters: A critical reader in Canadian mad studies, Toronto, Canada, Canadian Scholars Press.

Mason, T, 1983, Peter Sedgwick obituary, The Times, 20 September, http://www. petersedgwick.org/articles/biographical/TimesObituary.html

Morris, N, 2015, George Osborne urged by MPs and celebrities to end discrimination against people with mental health problems, The Independent, 1 November, http:// www.independent.co.uk/news/uk/politics/george-osborne-urged-by-mps-andcelebrities-to-end-discrimination-against-people-with-mental-health-a6717131. html 
O’Hagan, M, 1993, Stopovers on my way home from mars: A journey into the psychiatric survivor movement in the USA, Britain and the Netherlands, London: Survivors Speak Out

Oliver, M, Barnes, C, 1998, Disabled people and social policy: From exclusion to inclusion, London: Longman

Oliver, M, Barnes, C, 2012, The new politics of disablement, Basingstoke: Palgrave Macmillan

Pilgrim, D, Rogers, A, 1996, Mental health policy in Britain: A critical introduction (2nd edn), Basingstoke: Palgrave Macmillan

Ryan, F, 2015, Death has become part of Britain's benefits system, comment is free, The Guardian, 27 August, http://www.theguardian.com/commentisfree/2015/ aug/27/death-britains-benefits-system-fit-for-work-safety-net

Sedgwick, P, 1982, Psycho politics, London: Pluto Press

Sedgwick, P, 2015, Psycho politics (with a new Foreword) Unkant Publishers

Taylor-Gooby, P, 1985, Public opinion, ideology and state welfare, London: Routledge and Kegan Paul

Wallcraft, J, Read, J, Sweeney, A, 2003, On our own terms: Users and survivors of mental health services working together for support and change, London: Sainsbury Centre for Mental Health

Wilkinson, R, Pickett, K, 2009, The spirit level: Why more equal societies almost always do better, London: Bloomsbury Press. 